\author{
Febri Giantara ${ }^{1}$ \\ Kusdani $^{2}$ \\ Santi Afrida ${ }^{3}$
}

\title{
Peran Ayah Dalam Pendidikan Keluarga di Kota Pekanbaru
}

\begin{abstract}
Abstrak
Proses pendidikan pada manusia ada semenjak mereka dilahirkan. Pendidkan keluarga merupakan pintu utama yang membentuk kepribadian seseorang. Proses pendidkan keluarga yang dilakukan oleh Ayah pada saat ini di kota Pekanbaru adalah jarang bertanya kepada anak tentang apa yang terjadi dan dilakukan anak ketika berada di Sekolah dan ketika kepribadian anak tidak sesuai dengan norma adat, agama dan ketentuan masyarakat tempat tinggal maka Ayah akan menyalahkan Ibu yang tidak bisa mendidik sang anak. Penelitian ini memiliki tujuan ingin melihat bagaimana peran Ayah dalam pendidikan keluarga di kota Pekanbaru. Sebuah peran yang diharapkan mampu menghadirkan solusi yang terbaik bagi pendidikan keluarga bagi sang anak. Peneltian ini menggunakan rancangan penelitian kualitatif. Rancangan penelitian kualitatif yang digunakan di dalam penelitian ini adalah rancangan penelitian naratif. Peranan Ayah dalam pendidikan keluarga di kota Pekanbaru sudah berjalan dengan baik, terlihat pada Ayah sebagai pendidik, pelindung, pemberi rasa aman dan pendamping bagi anak-anak mereka.
\end{abstract}

\section{Kata Kunci: Peranan, Ayah, dan Pendidikan Keluarga}

\begin{abstract}
The human education process has been around since birth. Family education is the most important door that forms the personality of a person. The process of family education that Father is currently conducting in the city of Pekanbaru rarely asks the child about what happened and did the child at school and when the child's personality does not conform to the usual norms, religions and provisions of the community in which he lives, he will blame mother that the child cannot raise. This study wants to see the role of fathers in family education in the city of Pekanbaru. A role that is expected to be the best solution for family education for the child. This research uses a qualitative research design. The qualitative research design used in this study is a narrative research design. The role of father in family education in the city of Pekanbaru went well, is seen by my father as an educator, protector, security provider and a companion for their children.
\end{abstract}

Keywords: Role, father and family

\footnotetext{
${ }^{1}$ Pendidikan Agama Islam, STAI Diniyah Pekanbaru

Alamat email febri@ diniyah.ac.id

${ }^{2}$ Pendidikan Agama Islam, STAI Diniyah Pekanbaru

Alamatemail kusdani@diniyah.ac.id

${ }^{3}$ Pendidikan Agama Islam, STAI Diniyah Pekanbaru

Alamat email santiafrida84@gmail.com
} 


\section{PENDAHULUAN}

Keluarga merupakan tempat terbaik bagi anak-anak untuk menyampaikan aspirasi, tempat berbagi, dan tempat berlindung. Peran Ayah dan Ibu di dalam keluarga mempunyai kedudukan yang istimewa di mata anaka-anak. Pada saat ini ayah dan ibu mempunyai peran yang boleh dikatakan hampir sama. Ayah memiliki peran memberikan kecukupan nafkah kepada keluarga, bahkan juga diikuti oleh Ibu yang membantu kebutuhan keluarga tersebut. Peran utama Ibu adalah memastikan proses pendidikan anak di keluarga berjalan semestinya. Pemahaman Ibu yang bertanggung jawab atas keberlangsungan pendidikan anak di rumah membuat Ayah seolah-olah lepas tanggung jawab atas hal tersebut.

Dari segi perilaku, seorang anak akan menyerap pola perilaku yang umum berlaku di mana ia berada yang kemudian mengkristal pada tingkah lakunya. Anak-anak biasanya menggunakan timbangan akhlak sebagai pijakan dalam melihat segala bentuk kehidupan.

Perhatikan bagaimana Allah SWT. mengajarkan kepada kita setiap orang tua langkah demi langkah tentang cara mengenal diri kita dan bagaimana harus berakhlak di dunia ini;

Pertama, Allah SWT. menjelaskan tujuan penciptaan manusia dalam firman-Nya :

"Dan Aku tidak menciptakan jin dan manusia melainkan supaya mereka mengabdi kepada-Ku" (Q.S Adz Dzariyaat: 56).

Kedua, Allah SWT. mengajarkan dengan tegas, bahwa setiap ibadah yang kita lakukan kepada-Nya harus dikerjakan dengan ikhlas. Maka siapakah orang yang bisa ikhlas selain orang-orang yang memiliki akhlak dan budi pekerti yang baik? Lihat firman Allah SWT. berikut ini :

"Padahal mereka tidak disuruh kecuali supaya menyembah Allah dengan memurnikan ketaatan kepada-Nya dalam (menjalankan) agama yang lurus[1595], dan supaya mereka mendirikan shalat dan menunaikan zakat; dan yang demikian Itulah agama yang lurus" (Q.S Al-Bayyinah: 5).

Proses pendidkan keluarga yang dilakukan oleh Ayah pada saat ini di kota Pekanbaru adalah jarang bertanya kepada anak tentang apa yang terjadi dan dilakukan anak ketika berada di Sekolah dan ketika kepribadian anak tidak sesuai dengan norma adat, agama dan ketentuan masyarakat tempat tinggal maka Ayah akan menyalahkan Ibu yang tidak bisa mendidik sang anak (Obsevasi Oktober: 2019). Ini merupakan fenomena yang menurut peneliti perlu sebuah solusi agar ayah juga ikut berperan aktif dalam proses pendidikan keluarga pada sang anak.

Penelitian ini memiliki tujuan ingin melihat bagaimana peran Ayah dalam pendidikan keluarga di kota Pekanbaru. Sebuah peran yang diharapkan mampu menghadirkan solusi yang terbaik bagi pendidikan keluarga bagi sang anak.

Ayah di dalam sebuah keluarga memiliki tugas pokok yaitu (Gunarsah Yulia D, 2004):

1. Ayah sebagai pencari nafkah

Sebagai tokoh utama yang mencari nafkah untuk keluarga, mencari nafkah merupakan suatu tugas yang berat. Pekerjaan mungkin dianggap hanya sebagai suatu cara untuk memenuhi kebutuhan utama dan kelangsungan hidup.

2. Ayah sebagai suami yang penuh pengertian akan memberi rasa aman.

Ayah sebagai suami yang memberi keakraban, kemesraaan bagi istri. Hal ini sering kurang diperhatikan dan dilaksanakan. Padahal istri sebagai ibu, bila tidak mendapat dukungan keakraban dan kemesraan dari suami, bisa jemu terhadap semua kegiatan rumah tangga, mengurus keluarga, membesarkan anak dan pekerjaan di luar rumah, akhirnya uring-uringan dan cepat marah sehingga merusak suasana keluarga.

3. Ayah berpartisipasi dalam pendidikan anak.

Dalam hal pendidikan, peranan ayah di keluarga sangat penting. Terutama bagi anak laki-laki, ayah menjadi model, teladan untuk perannya kelak sebagai seorang laki-laki. Bagi anak perempuan, fungsi ayah juga sangat penting yaitu sebagai pelindung. 
4. Ayah sebagai pelindung atau tokoh yang tegas, bijaksana, dan mengasihi keluarga.

Seorang ayah adalah pelindung dan tokoh otoritas dalam keluarga, dengan sikapnya yang tegas dan penuh wibawa menanamkan pada anak sikap-sikap patuh terhadap otoritas, dan disiplin.

Keempat peran Ayah di atas menggambarkan keseluruhan dari kewajiban sang Ayah dalam keluarga. Keluarga bukan hanya sekedar adanya Ayah, Ibu dan Anak.

Pengertian keluarga sendiri menurut Ki Hajar Dewantara adalah kumpulnya beberapa orang yang karena terikat oleh satu turunan lalu mengerti dan merasa berdiri sebagai satu gabungan yang hak, dan berkehendak juga bersama-sama memperteguh gabungan itu untuk kemulian satu-satunya dan semua anggota. Mendidik anak harus dilakukan secara Ko-edukasi dan Ko-instruksi atau mendidik dan mengajar anak-anak perempuan dan laki-laki bersama-sama (Ki Hajar Dewantara, 2011).

Pentingnya pendidikan bersama-sama yang dijelaskan oleh Ki Hajar Dewantara di atas menunjukkan bahwa pendidikan keluarga tidak melihat jenis kelamin, artinya anak perempuan dan laki-laki berhak mendapatkan perlakuan yang sama pada proses pendidikan di keluarga. Pendidikan keluarga adalah proses pemberian nilai-nilai positif bagi tumbuh kembangnya anak sebagai fondasi pendidikan selanjutnya, menurut Mansur di dalam Nadwa (Jailani, 2014).

Progressivism "(1) a focus on the child as the learner rather than on the subject; (2) an emphasis on activities and experiences rather than an exclusive reliance on verbal and literary skills and knowledge; and (3) the encouragement of cooperative group learning activities rather than competitive individualized lesson learning" (Gerald Lee Gutek, 1974).

Filsafat pendidikan Progressivisme di atas menjelaskan, 1) Fokus pada anak sebagai pembelajar bukan pada subjek; 2) Penekanan pada kegiatan dan pengalaman daripada ketergantungan eksklusif pada keterampilan dan pengetahuan verbal dan sastra; dan 3) Dorongan kegiatan pembelajaran kelompok kooperatif daripada pembelajaran pelajaran individual yang kompetitif. Pendidikan di sini adalah sebuah pendidikan yang mengajarkan bagaiman anak harus mampu bekerjasama untuk memperoleh sebuah pengetahuan. Kerjasama bisa dilakukan salah satunya di dalam pendidikan keluarga yaitu kerjasama antara anak dan orang tua.

Menurut Al-Gazali dalam konsep pendidikan mengatakan bahwa pendidikan agama harus dimulai sejak usia dini. Sebab, dalam keadaan ini anak siap untuk menerima aqidah-aqidah agama semata-mata atas dasar iman, tanpa meminta dalil untuk menguatkannya, atau menuntut kepastian dan penjelasan. Oleh karena itu, dalam mengajarkan agama kepada anak-anak, hendaknya dimulai dengan menghafal kaidah-kaidah dan dasar-dasarnya. Setelah itu baru guru menjelaskan maknanya, sehingga mereka memahami, meyakini dan membenarkannya (Jailani, 2014).

Terkait pendidikan seorang anak, As Syeikh Kabir al-Majlisiy mengemukakan beberapa prinsip terkait pendidikan seorang anak, As Syeikh Kabir al-Majlisiy mengemukakan beberapa prinsip yang dilaksanakan Rasulullah SAW dalam mendidik anak di antaranya (Fadilah Ibnu Shidiq al-Qodiri, 2008):

1. Ajarilah anak membaca, menulis, berenang, dan memanah,

2. Cintailah anak dengan cinta yang sehat,

3. Berkatalah benar dan bila berjanji tepatilah,

4. Ciumlah anak-anak karena mencium anak adalah pahala,

5. Bermainlah dengan mereka seakan-akan anda seusianya,

6. Jangan berlaku diskriminatif terhadap anak kecuali karena ilmu dan kebaikan. 
Sebagai bahan pertimbangan dalam mendidik seorang anak, hendaknya puisi yang ditulis Dorothy Law Nolte yang berjudul Children Learn What They Live (anak-anak belajar dari kehidupan), yang telah diterjemahkan oleh Jalaludin Rahmat ini, patutlah kiranya dijadikan perenungan untuk semua (Fadilah Ibnu Shidiq al-Qodiri, 2008):

1. Jika anak dibesarkan dengan celaan, ia belajar memaki,

2. Jika anak dibesarkan dengan permusuhan, ia belajar berkelahi,

3. Jika anak dibesarkan dengan cemoohan, ia belajar rendah diri,

4. Jika anak dibesarkan dengan hinaan, ia belajar menyesali diri,

5. Jika anak dibesarkan dengan toleransi, ia belajar menahan diri,

6. Jika anak dibesarkan dengan dorongan, ia belajar percaya diri,

7. Jika anak dibesarkan dengan pujian, ia belajar menghargai,

8. Jika anak dibesarkan dengan sebaik-baiknya perlakuan, ia belajar keadilan,

9. Jika anak dibesarka dengan rasa aman, ia belajar menaruh kepercayaan,

10. Jika anak dibesarkan dengan dukungan, ia belajar menyenangi dirinya,

11. Jika anak dibesarkan dengan kasih sayang dan persahabatan, ia belajar menemukan cinta dalam kehidupan

\section{METODE}

Peneltian ini menggunakan rancangan penelitian kualitatif. Rancangan penelitian kualitatif yang digunakan di dalam penelitian ini adalah rancangan penelitian naratif. Riessman mengatakan penelitian naratif merupakan rancangan penelitian tentang kemanusian di mana peneliti mempelajari kehidupan individuindividu dan meminta seseorang atau sekelompok individu untuk menceritakan kehidupan mereka (Jhon Crewell, 2018).

Populasi adalah keseluruhan pengamatan yang menjadi perhatian kita dan sampel adalah himpunan bagian dari populasi menurut E. Walpole di dalam (Febri Giantara, 2019). Populasi dalam penelitian ini adalah masyarakat Kelurahan Tuah Karya Kecamatan Tampan Kota Pekanbaru. Sedangkan sampel dalam penelitian adalah warga perumahan Bumi Suka Damai yang memiliki anak usia 6-12 tahun. Subjek dalam penelitian ini adalah Ayah dan yang menjadi objek adalah peranan Ayah dalam pendidikan keluarga di kota Pekanbaru.

Teknik pengumpulan data penelitian menggunakan observasi dan wawancara. Observasi adalah tipe data teks tidak terstruktur dan gambar yang diambil selama observasi oleh peneliti dan wawancara adalah data teks tidak testruktur yang diperoleh dari mentranskripsikan rekaman audio wawancara (Jhon Crewell, 2015).

Analisis data kualitatif model Miles dan Huberman ada tiga macam kegiatan (Emzir, 2018), yaitu

1. Reduksi data merujuk pada proses pemilihan, pemokusan. Penyederhanaan, abstraksi, dan pentransformasian "data mentah" yang terjadi dalam catatan-catatan lapangan tertulis.

2. Model data (Display Data) sebagai suatu kumpulan informasi tersususn yang membolehkan pendeskripsian kesimpulan dan pengambilan tindakan.

3. Penarikan / Verifikasi Kesimpulan merupakan "makna" sesuatu, catatan keteraturan, pola-pola, penjelasan, konfigurasi yang mungkin, alur kausal, dan proposisi-proposisi 


\section{HASIL DAN PEMBAHASAN}

Berikut disajikan hasil wawancara dengan responden:

Tabel 1. Wawancara Responden Pertama

\begin{tabular}{|c|c|c|}
\hline No. & Pertanyaan & Jawaban \\
\hline 1 & $\begin{array}{l}\text { Sebagai kepala rumah tangga dan } \\
\text { seorang ayah, bagaimanakah } \\
\text { bapak memfasilitasi semua } \\
\text { kebutuhan keluarga? }\end{array}$ & $\begin{array}{l}\text { Semua saya serahkan dan percayakan kepada istri, } \\
\text { kecuali masalah pembayaran SPP dan kebutuhan } \\
\text { sekolah anak-anak. }\end{array}$ \\
\hline 2 & $\begin{array}{l}\text { Seperti apakah menurut bapak, } \\
\text { suami yang penuh pengertian dan } \\
\text { pemberi rasa aman bagi anak? }\end{array}$ & $\begin{array}{l}\text { Menurut saya, suami yang penuh pengertian itu } \\
\text { suami yang mengerti dengan situasi dan kondisi } \\
\text { istri. } \\
\text { Karena saya kerja dari pagi sampai malam dan hari } \\
\text { senin sampai hari sabtu, agar anak-anak tetap } \\
\text { aman jadi saya membuat aturan-aturan untuk anak- } \\
\text { anak agar mereka disiplin dalam menjalani } \\
\text { rutinitas. }\end{array}$ \\
\hline 3 & $\begin{array}{l}\text { Dalam hal pendidikan anak-anak, } \\
\text { sejauh mana bapak ikut } \\
\text { berpartisipasi? }\end{array}$ & $\begin{array}{l}\text { Karena saya seorang guru di sekolah tersebut, saya } \\
\text { biasanya memantau dan mengawasi perkembangan } \\
\text { mereka di sekolah dan memberi motivasi untuk } \\
\text { mereka. }\end{array}$ \\
\hline 4 & $\begin{array}{l}\text { Kita sebagai orang tua adalah } \\
\text { pendidik pertama bagi anak, } \\
\text { menurut bapak apakah seorang } \\
\text { ayah berperan penting dalam } \\
\text { mendidik anak? Mengapa? } \\
\text { Bagaimana? }\end{array}$ & $\begin{array}{l}\text { Iya tentu. } \\
\text { Karena ayah juga sebagai kepala keluarga yang } \\
\text { bertanggung jawab dalam hal mendidik. } \\
\text { Dalam mendidik anak, saya memberi teladan yang } \\
\text { baik bagi anak-anak. Contoh, shalat } 5 \text { waktu, } \\
\text { berkata-kata baik, sopan dan santun. }\end{array}$ \\
\hline 5 & $\begin{array}{l}\text { Menurut bapak, ayah yang tegas, } \\
\text { bijaksana dan mengasihi } \\
\text { keluarganya seperti apa? Apakah } \\
\text { bapak memberikan contoh? }\end{array}$ & $\begin{array}{l}\text { Seperti ketika anak berbuat salah atau keluar jalur, } \\
\text { kita arahkan dan luruskan dengan kelembutan dan } \\
\text { juga pandai bersikap adil terhadap anak-anak } \\
\text { dalam semua hal. } \\
\text { Iya tentu saya memberi contoh, saya tidak } \\
\text { langsung memarahi anak-anak ketika mereka } \\
\text { melakukan kesalahan. }\end{array}$ \\
\hline 6 & $\begin{array}{l}\text { Anak-anak biasa cepat meniru apa } \\
\text { yang kita ucapkan atau lakukan, } \\
\text { bagaimana cara bapak memberi } \\
\text { teladan yang baik bagi anak-anak? }\end{array}$ & $\begin{array}{l}\text { Kalau berbicara, nada bicara saya jaga, sopan dan } \\
\text { santun terhadap semua orang, saya juga } \\
\text { mengajarkan anak-anak untuk bersedekah. }\end{array}$ \\
\hline 7 & $\begin{array}{l}\text { Diantara kesibukan bekerja di luar } \\
\text { rumah, kapan bapak biasa } \\
\text { memberi arahan kepada anak- } \\
\text { anak? }\end{array}$ & $\begin{array}{l}\text { Kalau memberi arahan biasa sambil menonton } \mathrm{TV} \text {, } \\
\text { atau ketika libur. }\end{array}$ \\
\hline 8 & $\begin{array}{l}\text { Di mana dan seperti apakah biasa } \\
\text { bapak memberi nasehat kepada } \\
\text { anak-anak? }\end{array}$ & $\begin{array}{l}\text { Di rumah atau saat pergi jalan-jalan jadi lebih } \\
\text { masuk memberikan nasehat. }\end{array}$ \\
\hline 9 & $\begin{array}{l}\text { Ketika libur, bagaimanakah bapak } \\
\text { mengarahkan anak-anak mengisi } \\
\text { waktu luangnya? }\end{array}$ & $\begin{array}{l}\text { Hari minggu kita bebaskan kadang diajak gotong } \\
\text { royong. }\end{array}$ \\
\hline
\end{tabular}




\begin{tabular}{|c|c|c|}
\hline 10 & $\begin{array}{l}\text { Siapakah yang mendampingi } \\
\text { anak-anak saat belajar? }\end{array}$ & $\begin{array}{l}\text { Umumnya sih ibunya, tapi kalau pelajaran } \\
\text { matematika biasanya saya. }\end{array}$ \\
\hline 11 & $\begin{array}{l}\text { Apakah menyayangi dan } \\
\text { memperhatikan anak-anak } \\
\text { termasuk hal yang penting bagi } \\
\text { bapak? Mengapa? }\end{array}$ & $\begin{array}{l}\text { Penting. } \\
\text { Karena berpengaruh untuk masa depan mereka. }\end{array}$ \\
\hline 12 & $\begin{array}{l}\text { Seberapa sering bapak mencium } \\
\text { anak-anak? }\end{array}$ & Kalau $n$ \\
\hline 13 & $\begin{array}{l}\text { Kapankah biasanya bapak } \\
\text { bermain dengan anak-anak? }\end{array}$ & Har \\
\hline 14 & $\begin{array}{l}\text { Bagaimanakah cara bapak } \\
\text { bersikap adil terhadap anak-anak? }\end{array}$ & $\begin{array}{l}\text { Sama-sama diperhatikan dan disayang, uang jajan } \\
\text { juga disamakan karena mereka cuma beda } 2 \text { tahun. }\end{array}$ \\
\hline
\end{tabular}

Tabel 2. Wawancara Responden kedua

\begin{tabular}{|c|c|c|}
\hline No. & Pertanyaan & Jawaban \\
\hline 1 & $\begin{array}{l}\text { Sebagai kepala rumah tangga dan } \\
\text { seorang ayah, bagaimanakah bapak } \\
\text { memfasilitasi semua kebutuhan } \\
\text { keluarga? }\end{array}$ & Semua istri yang mengatur dan mengurus. \\
\hline 2 & $\begin{array}{l}\text { Seperti apakah menurut bapak, } \\
\text { suami yang penuh pengertian dan } \\
\text { pemberi rasa aman bagi anak? }\end{array}$ & $\begin{array}{l}\text { Memberikan perhatian, kasih sayang terhadap } \\
\text { semua anggota keluarga. }\end{array}$ \\
\hline 3 & $\begin{array}{l}\text { Dalam hal pendidikan anak-anak, } \\
\text { sejauh mana bapak ikut } \\
\text { berpartisipasi? }\end{array}$ & Saya mencarikan guru bimbel untuk anak-anak. \\
\hline 4 & $\begin{array}{l}\text { Kita sebagai orangtua adalah } \\
\text { pendidik pertama bagi anak, } \\
\text { menurut bapak apakah seorang ayah } \\
\text { berperan penting dalam mendidik } \\
\text { anak? Mengapa? Bagaimana? }\end{array}$ & $\begin{array}{l}\text { Penting, karena dari kitalah anak-anak } \\
\text { berperilaku baik atau tidaknya. } \\
\text { Kasih contoh yang bagus keanak-anak, missal } \\
\text { shalat berjamaah. Jadi kadang-kadang anak- } \\
\text { anak yang mengingatkan saya untuk shalat } \\
\text { berjamaah. }\end{array}$ \\
\hline 5 & $\begin{array}{l}\text { Menurut bapak, ayah yang tegas, } \\
\text { bijaksana dan mengasihi } \\
\text { keluarganya seperti apa? Apakah } \\
\text { bapak memberikan contoh? }\end{array}$ & $\begin{array}{l}\text { Tidak menggunakan amarah dalam } \\
\text { menyelesaikan masalah. } \\
\text { Iya. }\end{array}$ \\
\hline 6 & $\begin{array}{l}\text { Anak-anak biasa cepat meniru apa } \\
\text { yang kita ucapkan atau lakukan, } \\
\text { bagaimana cara bapak memberi } \\
\text { teladan yang baik bagi anak-anak? }\end{array}$ & depan anak-anak. \\
\hline 7 & $\begin{array}{l}\text { Diantara kesibukan bekerja di luar } \\
\text { rumah, kapan bapak biasa memberi } \\
\text { arahan kepada anak-anak? }\end{array}$ & $\begin{array}{l}\text { Setiap hari dan setiap ada kesempatan karena } \\
\text { saya liburnya tidak tentu. }\end{array}$ \\
\hline 8 & $\begin{array}{l}\text { Di mana dan seperti apakah biasa } \\
\text { bapak memberi nasehat kepada } \\
\text { anak-anak? }\end{array}$ & $\begin{array}{l}\text { Di mana-mana, kadang ketika sama-sama main } \\
\text { game, sambil main sambil saya nasehatin. }\end{array}$ \\
\hline 9 & $\begin{array}{l}\text { Ketika libur, bagaimanakah bapak } \\
\text { mengarahkan anak-anak mengisi }\end{array}$ & $\begin{array}{l}\text { Saya liburnya tidak selalu hari minggu, jadi } \\
\text { sayang jarang mengarahkan anak-anak, }\end{array}$ \\
\hline
\end{tabular}




\begin{tabular}{|c|c|c|}
\hline & waktu luangnya? & $\begin{array}{l}\text { keseringamn ibunya. Kadang dibawa jalan-jalan } \\
\text { kadang di rumah saja. }\end{array}$ \\
\hline 10 & $\begin{array}{l}\text { Siapakah yang mendampingi anak- } \\
\text { anak saat belajar? }\end{array}$ & Ibunya. \\
\hline 11 & $\begin{array}{l}\text { Apakah menyayangi dan } \\
\text { memperhatikan anak-anak termasuk } \\
\text { hal yang penting bagi bapak? } \\
\text { Mengapa? }\end{array}$ & $\begin{array}{l}\text { Penting, karena dengan cara itu anak-anak bisa } \\
\text { dekat dengan saya. }\end{array}$ \\
\hline 12 & $\begin{array}{l}\text { Seberapa sering bapak mencium } \\
\text { anak-anak? }\end{array}$ & $\begin{array}{l}\text { Kalau yang kecil sering, tapi abang-abangnya } \\
\text { sudah tidak mau. Mungkin faktor usia juga } \\
\text { karena mereka sudah agak besar. }\end{array}$ \\
\hline 13 & $\begin{array}{l}\text { Kapankah biasanya bapak bermain } \\
\text { dengan anak-anak? }\end{array}$ & Ketika saya libur kerja. \\
\hline 14 & $\begin{array}{l}\text { Bagaimanakah cara bapak bersikap } \\
\text { adil terhadap anak-anak? }\end{array}$ & $\begin{array}{l}\text { Memberi kasih sayang dan perhatian kesemua } \\
\text { anak-anak sesuai usianya, tidak ada yang saya } \\
\text { beda-bedakan. }\end{array}$ \\
\hline
\end{tabular}

Tabel 3. Wawancara Responden Ketiga

\begin{tabular}{|c|c|c|}
\hline No. & Pertanyaan & Jawaban \\
\hline 1 & $\begin{array}{l}\text { Sebagai kepala rumah tangga dan seorang } \\
\text { ayah, bagaimanakah bapak memfasilitasi } \\
\text { semua kebutuhan keluarga? }\end{array}$ & $\begin{array}{l}\text { Saya sih berbelanja bersama-sama dengan } \\
\text { istri. }\end{array}$ \\
\hline 2 & $\begin{array}{l}\text { Seperti apakah menurut bapak, suami yang } \\
\text { penuh pengertian dan pemberi rasa aman } \\
\text { bagi anak? }\end{array}$ & $\begin{array}{l}\text { Ikut serta membantu. Sebagai seorang } \\
\text { suami kalo pas sedang di rumah ketika } \\
\text { melihat istri pekerjaannya keteteran, saya } \\
\text { inisiatif membantu. Termasuk menjaga } \\
\text { dan mengawasi anak-anak. }\end{array}$ \\
\hline 3 & $\begin{array}{l}\text { Dalam hal pendidikan anak-anak, sejauh } \\
\text { mana bapak ikut berpartisipasi? }\end{array}$ & $\begin{array}{l}\text { Kalo untuk mengantar dan menjemput } \\
\text { anak-anak sekolah biasa ibunya. Semua } \\
\text { ibunya yang mengurus karena saya kerja. }\end{array}$ \\
\hline 4 & $\begin{array}{l}\text { Kita sebagai orangtua adalah pendidik } \\
\text { pertama bagi anak, menurut bapak apakah } \\
\text { seorang ayah berperan penting dalam } \\
\text { mendidik anak? Mengapa? Bagaimana? }\end{array}$ & $\begin{array}{l}\text { Ya berperan penting. Karena kalo anak } \\
\text { sukses kami sebagai orang tua juga } \\
\text { sukses. Mendidik secara langsung tidak, } \\
\text { saya inisiatif menentukan kegiatan anak- } \\
\text { anak di luar sekolah, seperti mengaji ke } \\
\text { mushala setelah mahgrib dan mengajak } \\
\text { shalat mahgrib dan isya berjamaah ke } \\
\text { mushala. }\end{array}$ \\
\hline 5 & $\begin{array}{l}\text { Menurut bapak, ayah yang tegas, bijaksana } \\
\text { dan mengasihi keluarganya seperti apa? } \\
\text { Apakah bapak memberikan contoh? }\end{array}$ & $\begin{array}{l}\text { Tegas tidak berarti marah, bijaksana itu } \\
\text { pandai menempatkan situasi dan kondisi, } \\
\text { mengasihi memperlakukan anak-anak } \\
\text { dengan kelembutan. } \\
\text { Iya, saya selalu memberikan contoh } \\
\text { dengan lisan dan sikap saya terhadap istri } \\
\text { dan anak-anak. }\end{array}$ \\
\hline 6 & $\begin{array}{l}\text { Anak-anak biasa cepat meniru apa yang } \\
\text { kita ucapkan atau lakukan, bagaimana cara }\end{array}$ & $\begin{array}{l}\text { Saya tidak berkata kasar terhadap istri } \\
\text { dan anak-anak. Dan biasa ketika saya di }\end{array}$ \\
\hline
\end{tabular}




\begin{tabular}{|c|c|c|}
\hline & $\begin{array}{l}\text { bapak memberi teladan yang baik bagi } \\
\text { anak-anak? }\end{array}$ & $\begin{array}{l}\text { rumah, saya ajak anak ke mushala ketika } \\
\text { masuk waktu shalat. }\end{array}$ \\
\hline 7 & $\begin{array}{l}\text { Diantara kesibukan bekerja di luar rumah, } \\
\text { kapan bapak biasa memberi arahan kepada } \\
\text { anak-anak? }\end{array}$ & Biasanya malam \\
\hline 8 & $\begin{array}{l}\text { Di mana dan seperti apakah biasa bapak } \\
\text { memberi nasehat kepada anak-anak? }\end{array}$ & $\begin{array}{l}\text { Di rumah, biasanya ketika anak-anak mau } \\
\text { tidur. Saya menemani sambil menasehati } \\
\text { mereka. }\end{array}$ \\
\hline 9 & $\begin{array}{l}\text { Ketika libur, bagaimanakah bapak } \\
\text { mengarahkan anak-anak mengisi waktu } \\
\text { luangnya? }\end{array}$ & $\begin{array}{l}\text { Mengajak mereka jalan-jalan, kadang } \\
\text { menemani mereka bermain di rumah. }\end{array}$ \\
\hline 10 & $\begin{array}{l}\text { Siapakah yang mendampingi anak-anak } \\
\text { saat belajar? }\end{array}$ & g ibunya, say \\
\hline 11 & $\begin{array}{l}\text { Apakah menyayangi dan memperhatikan } \\
\text { anak-anak termasuk hal yang penting bagi } \\
\text { bapak? Mengapa? }\end{array}$ & $\begin{array}{l}\text { Penting banget karena agar mereka } \\
\text { menjadi anak-anak yang shaleh dan } \\
\text { shalehah. }\end{array}$ \\
\hline 12 & $\begin{array}{l}\text { Seberapa sering bapak mencium anak- } \\
\text { anak? }\end{array}$ & Sering banget \\
\hline 13 & $\begin{array}{l}\text { Kapankah biasanya bapak bermain dengan } \\
\text { anak-anak? }\end{array}$ & Biasanya ketika saya libur kerja. \\
\hline 14 & $\begin{array}{l}\text { Bagaimanakah cara bapak bersikap adil } \\
\text { terhadap anak-anak? }\end{array}$ & $\begin{array}{l}\text { Kalo masalah uang jajan,saya berikan } \\
\text { sesuai tingkat kebutuhan mereka, kalo } \\
\text { perhatian dan kasih sayang itu sama. } \\
\text { Siapapun yang mendekat ke saya, pasti } \\
\text { saya ajak bercanda dan sayang. }\end{array}$ \\
\hline
\end{tabular}

Tabel 4. Wawancara Responden Keempat

\begin{tabular}{|l|l|l|}
\hline No. & \multicolumn{1}{|c|}{ Pertanyaan } & \multicolumn{1}{|c|}{ Jawaban } \\
\hline 1 & $\begin{array}{l}\text { Sebagai kepala rumah tangga dan seorang } \\
\text { ayah, bagaimanakah bapak memfasilitasi } \\
\text { semua kebutuhan keluarga? }\end{array}$ & Saya serahkan semua kepada istri 100\% \\
\hline 2 & $\begin{array}{l}\text { Seperti apakah menurut bapak, suami } \\
\text { yang penuh pengertian dan pemberi rasa } \\
\text { aman bagi anak? }\end{array}$ & $\begin{array}{l}\text { Kasih perhatian, ikut jaga anak dan } \\
\text { memberikan kasih sayang. Ketika saya di } \\
\text { rumah atau pulang kerja, saya ikut } \\
\text { mengawasi anak-anak ketika bermain. }\end{array}$ \\
\hline 3 & $\begin{array}{l}\text { Dalam hal pendidikan anak-anak, sejauh } \\
\text { mana bapak ikut berpartisipasi? }\end{array}$ & $\begin{array}{l}\text { Biasanya istri semua, saya tidak ikut } \\
\text { campur. Saya percayakan semua kepada } \\
\text { istri soal sekolah anak-anak }\end{array}$ \\
\hline 4 & $\begin{array}{l}\text { Kita sebagai orangtua adalah pendidik } \\
\text { pertama bagi anak, menurut bapak apakah } \\
\text { seorang ayah berperan penting dalam } \\
\text { mendidik anak? Mengapa? Bagaimana? }\end{array}$ & $\begin{array}{l}\text { Pentinglah, karena istri saja yang } \\
\text { mendidik kan tidak sepenuhnya bisa. } \\
\text { Seorang ayah kan lebih bertanggung } \\
\text { jawab.Saya biasa suka membelikan buku- } \\
\text { buku dan mainan yang mendidik untuk } \\
\text { anak-anak. }\end{array}$ \\
\hline 5 & $\begin{array}{l}\text { Menurut bapak, ayah yang tegas, } \\
\text { bijaksana dan mengasihi keluarganya } \\
\text { seperti apa? Apakah bapak memberikan }\end{array}$ & $\begin{array}{l}\text { Tegas selalu mengingatkan mereka, kalo } \\
\text { salah ya dibilang salah. Bijaksana marah } \\
\text { ketika mereka mlakukan kesalahan, }\end{array}$ \\
\hline
\end{tabular}




\begin{tabular}{|c|c|c|}
\hline & contoh? & $\begin{array}{l}\text { setelah itu saya sayang-sayang lagi. } \\
\text { Iya, contohnya dalam sikap saya sehari- } \\
\text { hari terhadap anak-anak. }\end{array}$ \\
\hline 6 & $\begin{array}{l}\text { Anak-anak biasa cepat meniru apa yang } \\
\text { kita ucapkan atau lakukan, bagaimana } \\
\text { cara bapak memberi teladan yang baik } \\
\text { bagi anak-anak? }\end{array}$ & $\begin{array}{l}\text { Berbicara yang baik-baik di depan anak- } \\
\text { anak, shalat ketika waktu shalat. }\end{array}$ \\
\hline 7 & $\begin{array}{l}\text { Diantara kesibukan bekerja di luar rumah, } \\
\text { kapan bapak biasa memberi arahan } \\
\text { kepada anak-anak? }\end{array}$ & $\begin{array}{l}\text { Malam hari ketika sedang duduk-duduk } \\
\text { sambil bercanda. }\end{array}$ \\
\hline 8 & $\begin{array}{l}\text { Di mana dan seperti apakah biasa bapak } \\
\text { memberi nasehat kepada anak-anak? }\end{array}$ & $\begin{array}{l}\text { Di rumah, biasanya saya dudukkan di } \\
\text { rumah ketika mereka berbuat salah. }\end{array}$ \\
\hline 9 & $\begin{array}{l}\text { Ketika libur, bagaimanakah bapak } \\
\text { mengarahkan anak-anak mengisi waktu } \\
\text { luangnya? }\end{array}$ & $\begin{array}{l}\text { Kalau pagi dibiarkan mereka main, siang } \\
\text { istirahat, kalau malam baru disuruh belajar } \\
\text { karena kan besoknya mereka masuk } \\
\text { sekolah. }\end{array}$ \\
\hline 10 & $\begin{array}{l}\text { Siapakah yang mendampingi anak-anak } \\
\text { saat belajar? }\end{array}$ & Istri, kadang ganti-gantian. \\
\hline 11 & $\begin{array}{l}\text { Apakah menyayangi dan memperhatikan } \\
\text { anak-anak termasuk hal yang penting bagi } \\
\text { bapak? Mengapa? }\end{array}$ & $\begin{array}{l}\text { Pentinglah, karena kalo kita cuek kan } \\
\text { kurang perhatianlah jatuhnya anak-anak. }\end{array}$ \\
\hline 12 & $\begin{array}{l}\text { Seberapa sering bapak mencium anak- } \\
\text { anak? }\end{array}$ & $\begin{array}{l}\text { Setiap hari, setiap mau pergi kerja, pulang } \\
\text { kerja dan mau tidur. }\end{array}$ \\
\hline 13 & $\begin{array}{l}\text { Kapankah biasanya bapak bermain } \\
\text { dengan anak-anak? }\end{array}$ & Malam hari, karena kerja tidak ada libur. \\
\hline 14 & $\begin{array}{l}\text { Bagaimanakah cara bapak bersikap adil } \\
\text { terhadap anak-anak? }\end{array}$ & $\begin{array}{l}\text { Sama-sama dimarahi kalau salah, mana } \\
\text { yang salah ditegur. Terus masalah kasih } \\
\text { sayang, ya sama-sama disayang walau } \\
\text { kadang sikakak sering cemburu karena } \\
\text { adeknya lebih disayang. Paling saya kasih } \\
\text { pengertian ke sikakak kalau adeknya } \\
\text { masih kecil belum mengerti dibilangin. }\end{array}$ \\
\hline
\end{tabular}

Tabel 5. Wawancara Responden Kelima

\begin{tabular}{|l|l|l|}
\hline No. & \multicolumn{1}{|c|}{ Pertanyaan } & \multicolumn{1}{|c|}{ Jawaban } \\
\hline 1 & $\begin{array}{l}\text { Sebagai kepala rumah tangga dan seorang } \\
\text { ayah, bagaimanakah bapak memfasilitasi } \\
\text { semua kebutuhan keluarga? }\end{array}$ & $\begin{array}{l}\text { Kasih uang keistri nanti dia yang belanja } \\
\text { untuk sandang dan pangan, kebutuhan } \\
\text { selebihnya kami berdua yang berbelanja. }\end{array}$ \\
\hline 2 & $\begin{array}{l}\text { Seperti apakah menurut bapak, suami } \\
\text { yang penuh pengertian dan pemberi rasa } \\
\text { aman bagi anak? }\end{array}$ & $\begin{array}{l}\text { Membantu hal yang tidak bisa dikerjakan } \\
\text { stri dan memberikan tempat tinggal yang } \\
\text { nyaman bagi anak. }\end{array}$ \\
\hline 3 & $\begin{array}{l}\text { Dalam hal pendidikan anak-anak, sejauh } \\
\text { mana bapak ikut berpartisipasi? }\end{array}$ & Menyediakan guru bimbel di rumah. \\
\hline 4 & Kita sebagai orangtua adalah pendidik & Penting, karena ayah memberikan \\
\hline
\end{tabular}




\begin{tabular}{|c|c|c|}
\hline & $\begin{array}{l}\text { pertama bagi anak, menurut bapak apakah } \\
\text { seorang ayah berperan penting dalam } \\
\text { mendidik anak? Mengapa? Bagaimana? }\end{array}$ & $\begin{array}{l}\text { pelajaran-pelajaran dalam sisi social dan } \\
\text { mental anak agar anak-anak bisa } \\
\text { menghadapi lingkugan sosialnya. } \\
\text { Biasa saya memberi contoh seperti } \\
\text { mengucap salam, mengucap terima kasih, } \\
\text { berkata tolong kalau saya menyuruh anak- } \\
\text { anak. }\end{array}$ \\
\hline 5 & $\begin{array}{l}\text { Menurut bapak, ayah yang tegas, } \\
\text { bijaksana dan mengasihi keluarganya } \\
\text { seperti apa? Apakah bapak memberikan } \\
\text { contoh? }\end{array}$ & $\begin{array}{l}\text { Tegas itu tidak harus marah-marah, } \\
\text { menyatakan hal ini benar ya benar jika } \\
\text { salah ya salah. Bijaksana ya memutuskan } \\
\text { segala sesuatu hal yang baik dengan tidak } \\
\text { membuat anak-anak tertekan. Mengasihi } \\
\text { itu menyayangi tapi bukan berarti } \\
\text { memanjakan. } \\
\text { Iya, saya memberikan contoh sehari-hari. }\end{array}$ \\
\hline 6 & $\begin{array}{l}\text { Anak-anak biasa cepat meniru apa yang } \\
\text { kita ucapkan atau lakukan, bagaimana } \\
\text { cara bapak memberi teladan yang baik } \\
\text { bagi anak-anak? }\end{array}$ & $\begin{array}{l}\text { Darikebiasaan saya sehari-hari, seperti } \\
\text { saya biasa berkata baik-baik, membuang } \\
\text { sampah pada tempatnya, mngucapkan } \\
\text { terima kasih, tolong, pinjam, salam, dan } \\
\text { kemushala shalat berjamaah. }\end{array}$ \\
\hline 7 & $\begin{array}{l}\text { Diantara kesibukan bekerja di luar rumah, } \\
\text { kapan bapak biasa memberi arahan } \\
\text { kepada anak-anak? }\end{array}$ & $\begin{array}{l}\text { Biasanya pulang kerja, hari libur dan } \\
\text { ketika mau tidur. }\end{array}$ \\
\hline 8 & $\begin{array}{l}\text { Di mana dan seperti apakah biasa bapak } \\
\text { memberi nasehat kepada anak-anak? }\end{array}$ & $\begin{array}{l}\text { Di rumah, seperti misalnya anak-anak } \\
\text { melakukan hal yang berbahaya dan salah, } \\
\text { saya menasehati dengan menjelaskan } \\
\text { kenapa dan mengapanya tidak boleh } \\
\text { dilakukan agar mereka memngerti. }\end{array}$ \\
\hline 9 & $\begin{array}{l}\text { Ketika libur, bagaimanakah bapak } \\
\text { mengarahkan anak-anak mengisi waktu } \\
\text { luangnya? }\end{array}$ & $\begin{array}{l}\text { Saya tidak selalu libur setiap hari minggu. } \\
\text { Biasa ketika libur, saya mengajak anak- } \\
\text { anak berenang atau jalan-jalan sekalian } \\
\text { sambil mendidik mereka bersosialisasi. }\end{array}$ \\
\hline 10 & $\begin{array}{l}\text { Siapakah yang mendampingi anak-anak } \\
\text { saat belajar? }\end{array}$ & Istri saya \\
\hline 11 & $\begin{array}{l}\text { Apakah menyayangi dan memperhatikan } \\
\text { anak-anak termasuk hal yang penting bagi } \\
\text { bapak? Mengapa? }\end{array}$ & $\begin{array}{l}\text { Menurut saya itu hal yang wajib, karena } \\
\text { itu akan berpengaruh kepada baik atau } \\
\text { buruknya psikologi anak-anak. }\end{array}$ \\
\hline 12 & $\begin{array}{l}\text { Seberapa sering bapak mencium anak- } \\
\text { anak? }\end{array}$ & Tidak terhitung. \\
\hline 13 & $\begin{array}{l}\text { Kapankah biasanya bapak bermain } \\
\text { dengan anak-anak? }\end{array}$ & $\begin{array}{l}\text { Pagi hari selepas shalat subuh ketika istri } \\
\text { saya masak, saya menemani anak-anak } \\
\text { bermain. Dan ketika saya cepat pulang }\end{array}$ \\
\hline
\end{tabular}




\begin{tabular}{|l|l|l|}
\hline & & $\begin{array}{l}\text { kerja, biasa saya ajak anak-anak jalan- } \\
\text { jalan keliling perumahan.a }\end{array}$ \\
\hline 14 & $\begin{array}{l}\text { Bagaimanakah cara bapak bersikap adil } \\
\text { terhadap anak-anak? }\end{array}$ & $\begin{array}{l}\text { Berhubung anak saya masih satu, jadi } \\
\text { semua tercurah untuk dia. }\end{array}$ \\
\hline
\end{tabular}

Hasil Analisis data wawancara di atas menunjukkan

1. Ayah tidak berperan dalam memfasilitasi semua kebutuhan keluarga, mereka menyerahkan sepenuhnya semua pengaturan dan kebutuhan keluarga kepada pasangannya.

2. Ayah berperan sebagai pemberi rasa aman bagi anak-anaknya dengan ikut serta mengawasi dan menjaga anak-anak.

3. Ayah berperan dalam hal pendidikan anak-anak dengan menyediakan guru bimbel, memotivasi anakanak dalam belajar, mencarikan sekolah yang bagus, bahkan sampai mengantar jemput anak sekolah.

4. Semua ayah berperan sebagai pendidik bagi anak-anaknya dengan memberikan teladan yang baik bagi anak-anaknya seperti shalat berjamaah ke mushala, berkata-kata baik, bersedekah, membiasakan mengucapkan salam, mengucapkan terima kasih, berkata maaf dan tolong, sopan dan santun. Memberikan sanksi yang mendidik atas kesalahan anak, mendukung dan memotovasi belajar anak dan memberikan tanggung jawab sesuai kapasitas anak-anak.

5. Ayah berperan sebagai pelindung atau tokoh yang tegas, bijaksana dan mengasihi keluarga dengan memperlakukan anak-anak penuh kelembutan dan ketegasan. Ketika menyelesaikan masalah, mereka mengarahkan dan menasehati anak-anak dengan kelembutan, kasih sayang dan bersikap adil.

6. Semua ayah berperan memberikan teladan yang baik kepada anak-anaknya dengan memberikan contoh yang baik dalam berkata dan bersikap. Contoh, berbicara baik dengan intonasi yang terjaga, melakukan shalat berjamaah di mushala dan bersedekah.

7. Semua ayah berperan sebagai pemberi arah bagi anak-anaknya. Mereka memanfaatkan waktu disaat istirahat atau menonton TV, ketika makan bersama, ketika libur atau jalan-jalan, sampai ketika mau tidur.

8. Ayah berperan sebagai penasehat, mereka menasehati anak-anak di rumah ketika anak-anak melakukan kesalahan atau hal-hal yang berbahaya. Mereka menjelaskan kenapa dan mengapanya tidak boleh dilakukan agar anak-anak mengerti.

9. Ayah berperan mengarahkan anak-anaknya mengisi waktu luang, mereka memanfaatkan kesempatan bersama anak-anak dengan pergi jalan-jalan, berenang, ke kebun binatang, bersilaturahim ke tempat sudara, pergi kepengajian atau tabliq, atau sekedar di rumah berkumpul bermain sambil mendidik anak-anak, dan bergotong royong membersihkan halaman.

10. Ayah tidak berperan dalam mendampingi anak belajar karena rata-rata yang mendampingi anak-anak belajar adalah pasangannya.

11. Semua ayah berperan menyayangi dan memperhatikan anak karena mereka menyadari bahwa dengan menyayangi dan memperhatikan anak-anak bisa berpengaruh untuk masa depan anak-anak, menciptakan anak-anak yang shaleh dan shalehah, berpengaruh terhadap psikologi anak-anak, mereka bisa lebih dekat dengan anak-anak, dan mereka menyadari kalau bukan mereka sebagai orangtua yang menyayangi dan memperhatikan anak-anak lalu siapa lagi.

12. Ayah berperan dalam menunjukkan kasih sayangnya dengan mencium anak-anaknya. Setiap hari, setiap ada kesempatan dan waktu selalu mencium anak-anaknya.

13. Ayah berperan dalam hal bermain dengan anak-anak, mereka bermain dengan anak-anak ketika pulang kerja, hari libur bahkan ada juga pagi sebelum berangkat kerja.

14. Ayah berperan dalam memperlakukan anak-anaknya secara adil dengan memperlakukan dan memberikan perhatian kasih sayang dan materi kepada anak secara sama sesuai tingkat usia dan kebutuhannya. 


\section{SIMPULAN}

Peranan Ayah dalam pendidikan keluarga di kota Pekanbaru sudah berjalan dengan baik, terlihat pada Ayah sebagai pendidik, pelindung, pemberi rasa aman dan pendamping bagi anak-anak mereka.

\section{DAFTAR PUSTAKA}

Emzir. (2018). Metodologi Penelitian Kualitatif Analisis Data. Depok: Rajawali Pers.

Fadilah Ibnu Shidiq al-Qodiri. (2008). Muiara Cinta Rasulullah. Yogyakarta: Surya Media.

Febri Giantara. (2019). Statistik Pendidikan dengan SPSS 21. (Yundri Akhyar, Ed.). Pekanbaru: LPPM STAI Diniyah Pekanbaru.

Gerald Lee Gutek. (1974). Philosophical Alternatives in Education. (A Bell \& Hewell Company, Ed.). Amerika: Charles E. Merrill Publishing Company.

Gunarsah Yulia D, G. S. D. (2004). Psikologi Praktis : Anak, Remaja dan Keluarga. Jakarta: Gunung Mulia.

Jailani, M. S. (2014). Teori Pendidikan Keluarga dan Tanggung Jawab Orang Tua dalam Pendidikan Anak Usia Dini. Nadwa, 8(2), 245. https://doi.org/10.21580/nw.2014.8.2.580

Jhon Creswell. (2015). Perencanaan, Pelaksanaan, dan Evaluasi Riset Kualitatif \& Kuantitif. In Riset Pendidikan (V, pp. 1-1364). Yogyakarta: Pustaka Pelajar.

Jhon Creswell. (2018). Pendekatan Metode Kualitatif, Kuantitatif, dan Campuran. In Research Design (IV, pp. 1-368). Yogyakarta: Pustaka Pelajar.

Ki Hajar Dewantara. (2011). Karya Ki Hajar Dewantara. In Pendidikan (Pendidikan, pp. 1-555). Yogyakarta: Majelis Luhur Persatuan Taman Siswa. 